\title{
Litigating Climate CHANGE - OF POLITICS AND POLITICAL QUESTIONS: A COMPARATIVE ANALYSIS OF JUSTICIABILITY OF CLIMATE CHANGE IN THE UNITED STATES AND CANADA
}

\author{
Inura Fernando*
}

\begin{abstract}
This article seeks to highlight the differences in the jurisprudence on the justiciability of climate change in Canada and the United States. Underpinning this article are questions about the appropriate role of the judiciary in addressing polycentric policy issues. This article will first outline the policy context in which legal issues of climate change are framed. Second, this article will explore the general doctrines of justiciability in Canada and the United States, and how these interrelate with specific doctrines on the justiciability of climate change. The author argues that, with respect to the justiciability of climate change, the approach of the courts in the United States is more principled than that of the Canadian courts, the Canadian approach being more broadly framed. This is because the United States approach encompasses the classic strand of the political questions doctrine. Conversely, though the courts in Canada deny the existence of an American-style political questions doctrine, they unwittingly follow its prudential strand. This has negative implications for legal reasoning. This means that despite contrary appearances from the United States executive, the courts in the United States provide a stronger framework for the protection of the climate.
\end{abstract}

Must our law be so rigid and our procedural concepts so inflexible that we render ourselves helpless when the existing methods and the traditional concepts do not quite fit and do not prove to be entirely adequate for new issues? ${ }^{1}$

* BHSc, LLB, LLM (Second Class, First Division Hons), University of Auckland. I would like to acknowledge the unerring love and support of my parents, Mala and Lal Fernando. I want to especially thank Professor Liz Fisher for her kind support and guidance.

1 Sierra Club v Morton 405 US 727 (1972) at 755-756 per Blackmun J dissenting. 


\section{INTRODUCTION}

The ice caps are melting. The globe is warming. The weather is becoming erratic. Climate change is happening. Climate change is a challenge facing all humanity. It is a collective problem. However, domestic western legal systems are based on individual rights and freedoms. This has an impact on what the courts will deem justiciable and adjudicate on. Should courts stick to traditional legal doctrines that limit the rights of individual litigants? A related question is whether climate change cases should be deemed to automatically involve non-justiciable political questions that should be dealt with by other branches of government such as Parliament or the executive.

Judicial reasoning is an inherently strange beast. Also, the complex multifaceted nature of climate change and the complexity of climate change cases inevitably will lead to challenges for domestic and international legal systems. There are also the traditional conceptions of justiciability and their interrelationship with climate change that is relevant here, namely that justiciability is strict in the United States and more relaxed in Canada. ${ }^{2}$ In analysing the judicial reasoning relating to the justiciability of climate change, it is imperative to ask whether the judiciary is "environmentally myopic" as Sir Harry Woolf states, ${ }^{3}$ or whether the judiciary is actively seeking to fill the "governance gap" left behind following poor responses to climate change on the part of the other branches of government. ${ }^{4}$ This approach gets to the truth of the notion that "the vital purpose of justiciability is to give courts a mechanism by which to avoid awkward cases". ${ }^{5}$ In canvassing these questions, this article will seek to illuminate the role of judges in legal jurisprudence.

The central thesis of this article is that, while judges in both the United States and Canada are influenced by general formulations of justiciability in shaping their position on the justiciability of climate change, the judges in the United States take a "more principled" route while the judicial approach in Canada is more broadly framed. ${ }^{6}$ This is because judges in America use their established political questions doctrine as a marker, ${ }^{7}$ even though some scholars do question its existence, ${ }^{8}$ which

2 Hugh S Wilkins "The Justiciability of Climate Change: A Comparison of US and Canadian Approaches" (2011) 34 Dalhousie LJ 529 at 529.

3 Harry Woolf "Are the Judiciary Environmentally Myopic?" (1992) 4 JEL 1 at 1.

4 Lisa Vanhala and Chris Hilson "Climate Change Litigation: Symposium Introduction" (2013) 35 Law \& Policy 141 at 143.

5 Jonathan R Siegel "A Theory of Justiciability" (2007) 86 Tex L Rev 73 at 108. See also Cass R Sunstein "Leaving Things Undecided" (1996) 110 Harv L Rev 4 at 51-52.

6 Wilkins, above n 2, at 545.

7 Ashley E Breakfield "Political Cases or Political Questions: The Justiciability of Public Nuisance Climate Change Litigation and the Impact on Native Village of Kivalina v Exxonmobil" (2011) 17 Hastings WNW J Envtl L \& Poly 39 at 39-40.

8 See Louis Henkin "Is there a 'Political Question' Doctrine?" (1976) Yale LJ 597 at 600-601. 
lays the path for greater clarity and consistency in legal reasoning. The legal test for justiciability laid out in Baker v Carr is a moot example. ${ }^{9}$ This has a flow-on effect on the conceptualisation of the justiciability of climate change. ${ }^{10}$ In this process, American judges, particularly in courts below the Supreme Court, ${ }^{11}$ favour the classic strand as opposed to the prudential strand of the political questions doctrine. ${ }^{12}$ It is argued that the focus on the classic strand strikes the right balance between certainty and judicial discretion. Otherwise "the boundary between political and legal questions" will remain blurred and it will continue to form a challenge for those on both sides of the debate. ${ }^{13}$ Equally, courts also have a remedies focus which is highlighted in cases such as Comer v Murphy Oil USA and Connecticut v American Electric Power Co Inc (AEP), ${ }^{14}$ which allow for principled distinctions to be made between cases that will have radically different impacts on public policy and the wider considerations underpinning justiciability. Conversely, judges in Canada, despite having denied the existence of an American-style political question doctrine, ${ }^{15}$ have nonetheless formulated justiciability in a manner that mirrors the prudential strand of the United States political questions doctrine in cases related to the justiciability of climate change such as Friends of the Earth $v$ Canada (Governor in Council) and Turp v Canada (Minister of Justice). ${ }^{16}$ Furthermore, Canadian courts in these cases, ${ }^{17}$ in their preference towards centralising statutory interpretation encouraged by United Kingdom case law, create a more broadly framed justiciability of climate change analysis than that afforded by the trend in the United States.

9 Baker v Carr 369 US 186 (1962) at 217.

10 See David Markell and JB Ruhl "An Empirical Assessment of Climate Change in the Courts: A New Jurisprudence or Business as Usual?" (2012) 64 Fla L Rev 15 at 77.

11 For a discussion of a lack of any clear judicial pronouncement on the justiciability of climate change at the Supreme Court level, see Hari M Osofsky "Litigation's Role in the Path of the US Federal Climate Change Regulation: Implications of AEP v Connecticut" (2012) 46 Val U L Rev 447 at 452-453.

12 Breakfield, above n 7 , at 43.

13 Lorne M Sossin Boundaries of Judicial Review: The Law of Justiciability in Canada (Carswell, Scarborough, 1999) at 133.

14 Comer v Murphy Oil USA 585 F 3d 855 (5th Cir 2009) at 874; and Connecticut v American Electric Power Co Inc 582 F 3d 309 (2nd Cir 2009) [AEP] at 325.

15 Lorne Sossin "The Unfinished Project of Roncarelliv Duplessis: Justiciability. Discretion, and the Limits of the Rule of Law" (2010) 55 Mcgill LJ 661 at 681. See also Operation Dismantle v The Queen [1985] 1 SCR 441 at $464-474$ per Wilson J.

16 Friends of the Earth v Canada (Governor in Council) 2008 FC 1183, [2009] 3 FCR 201 at [24]-[42]; and Turp v Canada (Minister of Justice) 2012 FC 893, [2014] 1 FCR 439 at [18]-[28].

17 Friends of the Earth, above n 16, at [26] and [33]. See also Turp, above n 16, at [25]. 
Admittedly, there are some limitations to this analysis. ${ }^{18}$ First, the United States has yet to implement a comprehensive legislative scheme on climate change at a federal level. ${ }^{19}$ Secondly, Canada has yet to face the type of tort-based, climate change-related nuisance claims that have heavily impacted the United States justiciability of climate change. ${ }^{20}$ However, because this article analyses the current position, while acknowledging that the law in this area is in a "constant state of flux" and affected by a complex web of factors, ${ }^{21}$ the current position is underpinned by patterns of judicial reasoning that support the position taken by this article.

This article is organised as follows. Part II will explore the context surrounding justiciability of climate change. Part III will explore how justiciability is defined in the United States and Canada. Part IV will explore how judges determine the justiciability of climate change in America and Canada respectively. Ultimately this article will conclude that overall the current prevailing judicial trend points to a principled approach in the United States compared to a broad-brush approach in Canada. This will, in turn, have important consequences for the development of legal jurisprudence and practical consequences for stakeholders involved.

\section{CONTEXT}

Jurisprudence on the justiciability of climate change exists in an unusual context. This context relates to the nature of climate change as a new legal discipline and the politics of climate change. It is imperative to understand that climate change law is a newly formed subset of the legal discipline and it is still growing. Further, the politics of climate change is vexed and encompasses what is termed the "polycentricity" of climate change. ${ }^{22}$ According to Professor Jacqueline Peel, climate change law "encompasses aspects of the existing environmental and broader legal framework, employing them in new ways to respond to aspects of the climate change problem". ${ }^{23}$ Equally, the polycentricity of climate change entails that "there are many different causes of climate change and those causes are complex in themselves". ${ }^{24}$ Professor Lon Fuller utilises the "spider web" metaphor to characterise this

18 For a discussion of some of the inherent challenges of environmental law scholarship that is also relevant in this context, see Elizabeth Fisher and others "Maturity and Methodology: Starting a Debate about Environmental Law Scholarship" (2009) 21 JEL 213 at 225-226.

19 Hari M Osofsky and Lesley K McAllister Climate Change Law and Policy (Wolters Kluwer, New York, 2012) at 118 .

20 Wilkins, above n 2, at 538.

21 Elizabeth Fisher "Environmental Law as 'Hot' Law" (2013) 25 JEL 347 at 347.

22 Elizabeth Fisher, Bettina Lange and Eloise Scotford Environmental Laws: Text, Cases, and Materials (Oxford University Press, Oxford, 2013) at 24.

23 Jacqueline Peel "Climate Change Law: The Emergence of a New Legal Discipline" (2008) 32 MULR 922 at 927.

24 Fisher, Lange and Scotford, above n 22, at 24. 
state of affairs. ${ }^{25}$ Some of the key challenges of this new climate change law discipline centre on the marriage between science and law. The scholarship of Sara Aminzadeh highlights the intricacies of establishing damage to the environment brought on by climate change in scientific terms. ${ }^{26}$ These intricacies mean that there are difficulties in achieving legal redress for claims based on climate science. ${ }^{27}$ Equally, Professor Hari M Osofsky notes: "Climate change petitions do not fit neatly into this mainstream discussion of judicial dialogue." 28 There is a melding between the national and international law that is added to the mix. ${ }^{29}$

Some may argue that, though climate change is new, the law has had many challenges along the way that shook its core. So why then should time honoured legal principles be changed for this socalled new discipline? There has always been a contest of rights in most legal issues, and climate change is no different. There are those who will be the losers from climate change, while there will be those who will benefit. ${ }^{30}$ However, climate change law cuts across many fields and there are no binary solutions that would justify recourse to some generalist argument about a contest of rights. As Professor Liz Fisher notes: "Decision making about the environment is not an exercise that individuals can take in isolation." 31 It is an issue of more than two groups of winners and losers. There are spectrums of winners and losers, and others that will fall beyond a strict prisoner's dilemma scenario. ${ }^{32}$ Therefore, developing a climate change jurisprudence that is appropriate and allows for a collaborative response to climate change will be crucial. The judiciary will play a significant part in this response. ${ }^{33}$

An interesting perspective on climate change is put forward by indigenous peoples, whose culture and way of life is intimately tied to the environment. ${ }^{34}$ Also as Sara Aminzadeh notes: "Indigenous

25 Lon L Fuller "The Forms and Limits of Adjudication" (1978) 92 Harv L Rev 353 at 395.

26 Sara C Aminzadeh "A Moral Imperative: The Human Rights Implications of Climate Change" (2007) 30 Hastings Intl \& Comp L Rev 231 at 233.

27 At 233 .

28 Hari M Osofsky "Climate Change Litigation as Pluralist Legal Dialogue?" (2007) 43A Stan J Intl L 181 at 192.

29 At 192 .

30 See generally John S Dryzek, Richard B Norgaard and David Schlosberg Climate-Challenged Society (Oxford University Press, Oxford, 2013). See also JB Ruhl "The Political Economy of Climate Change Winners" (2012) 97 Minn L Rev 206 at 207-240.

31 Fisher, Lange and Scotford, above n 22, at 24.

32 See generally Richard H McAdams "Beyond the Prisoners' Dilemma: Coordination, Game Theory, and Law" (2009) 82 S Cal L Rev 209 at 225-236.

33 See Brian J Preston "The Contribution of the Courts in Tackling Climate Change" (2016) 28 JEL 11 at 11.

34 Aminzadeh, above n 26, at 254-255. 
peoples often inhabit some of the world's most vulnerable ecosystems and suffer some of the worst effects of environmental degradation". ${ }^{35}$ Despite being disproportionately affected by climate change, indigenous peoples are often left marginalised by the judicial dialogue as seen in case law relating to the Arctic Inuit and climate change. ${ }^{36}$

Environmental law is tritely described as "hot" law. ${ }^{37}$ However, if environmental law is "hot" law, then climate change law must be "super hot" law. It is important to understand the context in which legal reasoning relating to climate change operates. It is not a binary world in the least. It is one of shifting causes and shifting truths. It is one of the multiple stakeholders on many different levels. It is one of multiple perspectives. It is one that is apt for scholarly dialogue.

\section{HOW IS JUSTICIABILITY DEFINED?}

Before venturing into discussions on the justiciability of climate change, it is first imperative to explore how justiciability in a general sense is defined in both the United States and Canada. There are nuances in the legal pronouncement on justiciability between the United States and Canada. The nuance is that the Canadian legal definition is "fragmented"38 and broadly framed whereas the United States definition is more tightly framed, ${ }^{39}$ as per the test in Baker. ${ }^{40}$ The United States approach also encompasses a specific doctrine known as the political questions doctrine, which has two central strands, the classic and prudential strands. ${ }^{41}$ The classic strand is based on the "text, structure, and history of the constitution itself", ${ }^{42}$ whereas the prudential strand "does not involve constitutional interpretation but rather a judge-made overlay used to avoid conflicts with other branches and to avoid embarrassment". ${ }^{43}$ This nuance, however, is not immediately obvious from a cursory glance of the respective legal dictionary definitions of justiciability. The Black's Law Dictionary defines justiciability as "the quality, state or condition of being appropriate or suitable for adjudication by a

35 At 255

36 See generally Inuit Circumpolar Council Canada "Inuit Petition Inter-American Commission On Human Rights To Oppose Climate Change Caused By The United States Of America" (press release, 7 December 2005).

37 Fisher, above n 21, at 347.

38 Wilkins, above n 2, at 543.

39 At 543-545.

40 Baker, above n 9, at 217.

41 Rachel E Barkow "More Supreme Than Court? The Fall of the Political Question Doctrine and the Rise of Judicial Supremacy" (2002) 102 Colum L Rev 237 at 253.

42 At 253

43 At 253 
court". ${ }^{44}$ Equally, The Dictionary of Canadian Law puts forward a similar definition, although as a point of mild difference, it incorporates the notion of "judicial restraint" into the definition. ${ }^{45}$

In order to outline the fragmentation in the Canadian legal definition of justiciability, it is necessary to understand the different strands of case law. ${ }^{46}$ One strand encourages a more relaxed approach to justiciability while the other strand is stricter and broadly framed. The cases heralding the relaxed approach are Operation Dismantle $v$ The Queen and Finlay v Canada (Minister of Finance). ${ }^{47}$ The approach in Operation Dismantle was very much affected by the fact that it was a challenge under s 7 of the Canadian Charter of Rights and Freedoms. ${ }^{48}$ Nevertheless, Wilson J emphasised that "courts should not be too eager to relinquish their judicial review function simply because they are called upon to exercise it in relation to weighty matters of states". ${ }^{49}$ Equally, in agreeing with Wilson J's approach, Dickson CJ finds "no doubt that disputes of a political or foreign policy nature may be properly cognizable by the courts". 50

Equally, the Court in Finlay cites the Operation Dismantle approach in relation to the justiciability issue and notes that: 51

That was, of course, said in the context of the judicial duty to rule on an issue of constitutionality under the Charter, but take it to be equally applicable to a non-constitutional issue of the limits of statutory authority.

Conversely, the strict approach is heralded by cases such as Reference Re Canada Assistance Plan (BC) and Canada (Auditor General) v Canada (Minister of Energy, Mines and Resources). ${ }^{52}$ In Reference Re Canada Assistance Plan (BC), the Court affirmed the approach of Auditor General and Borowski v Canada (Attorney General), ${ }^{53}$ and concluded that "the Court's primary concern is to retain

44 Bryan A Garner (ed) Black's Law Dictionary (10th ed, Thomson Reuters, St Paul, 2014) at 997.

45 Daphne A Dukelow The Dictionary of Canadian Law (4th ed, Carswell, Toronto, 2011) at 698.

46 Wilkins, above n 2, at 543-544.

47 Operation Dismantle, above n 15; and Finlay v Canada (Minister of Finance) [1986] 2 SCR 607.

48 Operation Dismantle, above n 15, at 447. See also Canadian Charter of Rights and Freedoms, pt 1 of the Constitution Act 1982, being sch B to the Canada Act 1982 (UK).

49 At 471 per Wilson $\mathbf{J}$.

50 At 459 per Dickson CJ.

51 Finlay, above n 47, at 632 per Le Dain J (emphasis added).

52 Reference Re Canada Assistance Plan (BC) [1991] 2 SCR 525; and Canada (Auditor General) v Canada (Minister of Energy, Mines and Resources) [1989] 2 SCR 49 [Auditor General].

53 See Auditor General, above n 52, at 90-91; and Borowski v Canada (Attorney General) [1989] 1 SCR 342 at 362. 
its proper role within the constitutional framework of our democratic form of government". ${ }^{54}$ In determining the legal issue posed, Sopinka J utilised a two-pronged test. First, the court has to ascertain, "whether the question is purely political in nature and should, therefore, be determined in another forum". ${ }^{55}$ Secondly, the court has to determine whether the matter has a "sufficient legal component to warrant the intervention of the judicial branch". 56

Fragmentation occurs between the strands because each strand has different starting points. The relaxed strand "starts from the position that, with some exceptions, most policy related matters should be justiciable", 57 whereas the strict strand of justiciability "starts from the position that most policyrelated matters should be left to the legislature". ${ }^{58}$

In understanding the American definition of justiciability, legal history provides a useful starting point. The American political questions doctrine had its root in the seminal case, Marbury $v$ Madison. ${ }^{59}$ Although the legal principle comes from this case, it was said to be not applicable to the facts of this case. ${ }^{60}$ Justice Marshall framed political questions as: "Questions, in their nature political, or which are, by the constitution and laws, submitted to the executive, [and] can [thus] never be made in this court". ${ }^{61}$ Equally, Marshall J noted that: ${ }^{62}$

... where the heads of departments are the political or confidential agents of the executive, merely to execute the will of the President, or rather to act in cases in which the executive possesses a constitutional or legal discretion ... their acts are only politically examinable.

However, Marshall $\mathbf{J}$ "went on to rule for the Court that the government's legal duty to furnish Marbury's promised commission to serve as a justice of peace was not such a situation". ${ }^{63}$ As Professor Phillip Weinberg notes: ${ }^{64}$

54 Reference Re Canada Assistance Plan (BC), above n 52, at 545 per Sopinka J.

55 At 545 per Sopinka J.

56 At 545 per Sopinka J.

57 Wilkins, above n 2, at 544 .

58 At $544-545$.

59 Marbury v Madison 5 US 137 (1803).

60 Phillip Weinberg "'Political Questions': An Invasive Species Infecting the Courts" (2008) 19 Duke Envtl L \& Poly F 155 at 156.

61 Marbury, above n 59, at 170

62 At 166

63 Weinberg, above n 60, at 156.

64 At 156 
This decision, establishing the power of judicial review, of course veered off to hold the provision of the Judiciary Act of 1789 empowering the Supreme Court to issue writs of mandamus in its original jurisdiction cases to be unconstitutional.

Nevertheless, Marshall J's judgment in Marbury has come to epitomise the classical strand of the political questions doctrine. ${ }^{65}$ Justice Marshall's approach was very much influenced by his contemporaries, namely Alexander Hamilton and his writings in The Federalist Papers about separation of powers, judicial review and the judiciary's place in the constitutional apex. ${ }^{66}$ However, the approach in Marbury was not the end of the matter and some argue that it created an "interpretive vacuum". ${ }^{67}$ Along with the Great Depression, changes had come to America and its socio-political landscape in the New Deal era of the 1930s. ${ }^{68}$ The political question doctrine changed during this period from one that centralised constitutional interpretation to one that centralised prudential concerns and judicial restraint. ${ }^{69}$ The prudential approach involved "courts looking not to the text of the Constitution itself, but rather to the consequences of the case in contemplating whether a political question exists". ${ }^{70}$ Some scholars have expressed caution over the prudential approach, namely the risk that courts will seek to forgo cases which are "too complicated or too politically charged". ${ }^{71}$

The motif of change continued and Baker $v$ Carr represented a watershed that provided political questions doctrine the "detailed structure" it needed. ${ }^{72}$ The Court in Baker laid out the six key elements of the classical formulation of justiciability in the United States. ${ }^{73}$ In order to be deemed a political question, a case needed to have at least one of the following six elements. First, there needs to be a "textually demonstrable constitutional commitment of the issue to a coordinate political

65 Barkow, above n 41, at 253. See also Robert J Pushaw "Judicial Review and the Political Question Doctrine: Reviving the Federalist Rebuttable Presumption' Analysis" (2002) 80 NC L Rev 1165 at 1192-1193.

66 Jill Jaffe "The Political Question Doctrine: An Update in Response to Recent Case Law" (2011) 38 Ecology LQ 1033 at 1037. See also Alexander Hamilton The Federalist: A Collection of Essays, Written in Favour of the New Constitution, as Agreed upon by the Federal Convention, September 17, 1787 (J \& A McLean, New York, 1788).

67 Breakfield, above $\mathrm{n} 7$, at 43 .

68 See generally GE White The Constitution and the New Deal (Harvard University Press, Cambridge (Mass), 2002).

69 Gregory Bradford "Simplyfing State Standing: The Role of Sovereign Interests in Future Climate Litigation" (2011) 52 BC L Rev 1065 at 1080.

70 Breakfield, above n 7, at 43.

71 Barkow, above n 41, at 263.

72 Breakfield, above n 7, at 43.

73 Baker, above n 9, at 217. 
department". ${ }^{74}$ Secondly, the "lack of judicially discoverable and manageable standards for resolving it". ${ }^{75}$ Thirdly, whether there is the "impossibility of deciding without an initial policy determination of a kind clearly for non-judicial discretion". ${ }^{76}$ Fourthly, whether there is "the impossibility of a court's undertaking independent resolution without expressing lack of the respect due to coordinate branches of government". ${ }^{77}$ Fifthly, whether there is an "unusual need for unquestioning adherence to a political decision already made". ${ }^{78}$ Finally, whether there is "the potentiality of embarrassment from multifarious pronouncements by various departments on one question". ${ }^{79}$

The Baker test represents an amalgam of the classic and prudential approaches. The first two parts of the test, relating to constitutional commitment and judicial standards, represents the classic approach, ${ }^{80}$ while the latter four parts of the Baker test reflects prudential concerns. ${ }^{81}$ Even though the Baker test is not necessarily an exhaustive articulation of justiciability, it does entail "a narrowed scope" of the political questions doctrine. ${ }^{82}$

In sum, the fragmented Canadian approach means that while justiciability in Canada is more akin to a "broader spectrum of judicial oversight", ${ }^{83}$ the American approach is closer to "an on/off switch". ${ }^{84}$ The nature of judicial reasoning is so fraught that a notion of an "on/off switch" is not a practical ideal. The best that can be hoped for is a greater degree of clarity and enumeration, which is not necessarily the same as bright-line distinctions. ${ }^{85}$

74 At 217

75 At 217.

76 At 217

77 At 217

78 At 217

79 At 217.

80 Breakfied, above $\mathrm{n} 7$, at 44

81 At 44 .

82 At 44 .

83 Sossin, above n 15, at 666.

84 At 666.

85 See generally James G Wilson "Surveying the Forms of Doctrine on the Bright Line-Balancing Test Continuum" (1995) 27 Ariz St LJ 773 at 773-807. 


\section{FACTUAL UNDERPINNINGS OF KEY CASES ON JUSTICIABILITY OF CLIMATE CHANGE LAW}

In terms of the United States case law on the justiciability of climate change, it is important to understand the factual underpinnings of cases such as AEP and Comer v Murphy. ${ }^{86}$ In AEP, the Second Circuit of the United States Court of Appeals was presented with a situation symptomatic of effects of climate change on society. The plaintiffs in this case included the States of New York, California, Iowa, New Jersey, Rhode Island, Vermont, Wisconsin, the City of New York and three land trusts. ${ }^{87}$ In 2004 these plaintiffs sought the remedy of abatement against American Electric Power Inc and five other electricity companies, for the "ongoing contributions to the public nuisance of global warming". ${ }^{88}$ In 2005 the United States District Court held that these claims inevitably involved "an initial policy determination of a kind clearly for non-judicial discretion". 89 Therefore it ruled that the claims were barred under the political questions doctrine. On appeal to the Court of Appeals, the plaintiffs contended that these claims have standing and are justiciable. ${ }^{90}$ Equally, they argued that they have appropriately fashioned their claims by recourse to the law of nuisance and that "these claims are not displaced by federal statutes". ${ }^{91}$ On the other hand, the defendants sought to reaffirm the District Court position, that these claims were non-justiciable, lacked standing, failed to state a claim and that federal common law had been displaced by federal statutes. ${ }^{92}$

In Comer v Murphy, the Fifth Circuit of the United States Court of Appeals considered the claims of nuisance (both public and private), trespass, negligence, unjust enrichment, fraudulent misrepresentation and civil conspiracy against oil and energy companies operating in the Mississippi Gulf Coast. ${ }^{93}$ These claims were brought by land owners in the area who asserted that operations of these companies contributed to a cascade of events that culminated in hotter surface air and water, as well as an increase in sea levels. ${ }^{94}$ This is said to have increased the strength of Hurricane Katrina, which in turn damaged both buildings owned by the landowners and public facilities in the area. ${ }^{95}$ In

$86 A E P$, above n 14; and Comer, above n 14.

$87 A E P$, above n 14 , at 314

88 At 314

89 Connecticut v American Electricity Power Co Inc 406 F Supp 2d 265 (SD NY 2005) at 274.

$90 A E P$, above n 14 , at 314

91 At 314 .

92 At $314-315$.

93 Comer, above n 14, at 859-860.

94 At 859 .

95 At 859 
contrast, the defendants in Comer v Murphy sought to challenge these claims on the grounds of lack of standing and non-justiciability via the political questions doctrine. ${ }^{96}$

The factual underpinnings of the Canadian case law, as seen in Friends of the Earth and Turp, are different to the United States case law. The main difference is that both Canadian cases revolve around the specific legislation passed to deal with climate change, namely the Kyoto Protocol Implementation Act 2007 (KPIA). ${ }^{97}$ In Friends of the Earth, the Federal Court was presented with its first opportunity to review the KPIA. ${ }^{98}$ The applicant in this case was a non-governmental organisation seeking to protect the natural environment. ${ }^{99}$ The applicant brought a judicial review action seeking declaratory and mandatory relief in relation to the KPIA. ${ }^{100}$ Namely, the applicant alleged breaches of s 5 of the KPIA due to the failure of the Environment Minister to prepare an initial Climate Change Plan. ${ }^{101}$ Also, it alleges breaches of ss 7 and 8-9 of the KPIA on the part of the Governor in Council (GIC). This is because the GIC failed to carry out the requirements in relation to publishing and repeal of inconsistent provisions in relation to proposed regulations within the time deadlines prescribed in the KPIA, in order for Canada to meet its Kyoto Protocol obligations. ${ }^{102}$ The arguments of the applicant emphasise the language utilised in the KPIA. ${ }^{103}$ Conversely, the respondent contended that the claims presented by the applicant are non-justiciable because "they are not properly suited or amenable to judicial review". ${ }^{104}$ This thesis is supported by notions of deference to the policy choices made by Parliament. In other words, the respondent argues that "accountability for their failure to fulfil Canada's Kyoto obligations will be at the ballot box and cannot be in the courtroom". ${ }^{105}$ In Turp, the Federal Court considered a judicial review of the "decision of the Government of Canada to withdraw from the Kyoto Protocol ... which was communicated to the Secretary-General of the United Nations ... on December 15, 2011". ${ }^{106}$ The applicant in Turp stated that: ${ }^{107}$

96 At 860

97 Kyoto Protocol Implementation Act SC 2007 c 30.

98 See Friends of the Earth, above n 16, at [1]-[7].

99 At [1].

100 At [2].

101 At [3].

102 At [4]-[5].

103 At [6].

104 At [7].

105 At [7].

106 Turp, above n 16, at [1].

107 At [13]. 
The withdrawal from the Protocol is illegal, null, and void as it is in violation of the KPIA, the principle of the rule of law, the principle of the separation of powers, and the democratic principle.

The defendant in Turp, the Attorney-General of Canada, contended that: ${ }^{108}$

... the conduct of foreign affairs, including the decision to conclude or withdraw from an international treaty, is a matter falling within the royal prerogative and thus the executive branch of government.

\section{ANALYSIS}

\section{A How do Judges Determine the Justiciability of Climate Change in the United States?}

\section{The Baker test and the flow-on effects of how justiciability is defined}

A key argument on the notion that the American judicial approach to the justiciability of climate change follows a principled route relates to the flow-on effects of the Baker test. This is not only an argument about the flow-on effects of the general jurisprudence on justiciability to specific jurisprudence on the justiciability of climate change; it is also an argument about the intricacies of the Baker test. Namely, the incorporation of both the classic strand and the prudential strand in the Baker test makes for greater legal certainty. Also, the legal test in Baker is genius in terms of separating discrete legal and constitutional imperatives so as to avoid confusion and inconsistency.

The Supreme Court in Baker made a painstaking effort to emphasise that: "The doctrine which we treat is one of 'political questions,' not one of 'political cases"', ${ }^{109}$ whereas this concern is less emphasised in the prevailing Canadian approach. ${ }^{110}$ Equally, the Court in AEP found that in considering the political implications of setting emission standards that "it is [an] error to equate a political question with a political case". ${ }^{111}$ The lack of a clear approach on the justiciability of climate change at the Supreme Court level in $A E P^{112}$ means that the lower courts' approach stands as the prevailing approach. As David Markell and JB Ruhl note, there is no "distinctive jurisprudence of climate change" that can be separated from the general justiciability jurisprudence. ${ }^{113}$ This is turn heightens the importance of the Baker test.

108 At [14].

109 Baker, above n 9, at 217.

110 See discussion in Part IV(B)

111 AEP, above n 14 , at 332

112 See generally American Electric Power Co Inc v Connecticut 564 US 410 (2011).

113 Markell and Ruhl, above n 10, at 77. 
As the Second Circuit noted in $A E P:^{114}$

Baker set a high bar for non-justiciability: Unless one of these formulations is inextricable from the case

bar there should be no dismissal for non-justiciability on the ground of a political question presence.

Some would argue that greater theorisation in a legal test does not necessarily lead to a principled approach and it can even lead to a rigid approach to a multifaceted legal question. ${ }^{115}$ However, as noted in Comer v Murphy the Baker formulation was not meant to be a legal straightjacket, but rather "open textured, interpretive guides to aid federal courts"116 and that "the Baker formulations are not self sufficient definitions". ${ }^{117}$ The "open textured" approach to Baker has allowed the courts to make principled distinctions, while still utilising the framework laid out by Baker. ${ }^{118}$ In AEP, the second circuit found the defendants lacking in failing to "explain how the emissions issues is textually committed to the Commerce clause [of the United States Constitution]". ${ }^{119}$ Equally, the Second Circuit in AEP disagreed with the defendants that "there are no judicially discoverable and manageable standards for settling this case"120 and that "[w]ell settled principles of tort and public nuisance law provide appropriate guidance."121

A key flow-on effect of the Baker test is greater theorisation in the judicial approach on justiciability of climate change in America. This enumeration lays the path for principled reasoning and in turn, leaves the American courts less likely to be scouring to maintain an "incomplete" theorisation. ${ }^{122}$ This is not the same as full theorisation and the raison d'être of the case representing the prevailing approach has flexibility in it, while not becoming out of touch with the established framework.

\section{The use of the classic strand of the political questions doctrine}

The use of the classic strand of the political questions doctrine in the cases about justiciability of climate change is one of the key arguments suggesting that the American approach is a more principled one. This is particularly seen in the prevailing approach in courts below the Supreme Court,

114 AEP, above n 14, at 321 (emphasis added).

115 See Thomas O McGarity "Some thoughts on 'Deossifying' the Rule Making Process" (1992) 41 Duke LJ 1385 at 1386-1387.

116 Comer, above n 14, at 872.

117 At 872 .

118 At 872 .

119 AEP, above n 14, at 324.

120 At 329

121 At 329.

122 Cass R Sunstein "Incompletely Theorized Agreements" (1995) 108 Harv L Rev 1733 at 1733. 
in cases such as Comer $v$ Murphy and AEP. The classical strand, which encompasses the first part of the Baker test, asks is "there a textually demonstrable constitutional commitment of the issue to a coordinate political department?"123 The Federal Court of Appeals in AEP affirmed the approach of Lamont $v$ Woods in holding that this first factor is the "dominant consideration in any political question inquiry". ${ }^{124}$ The reason why it is a more principled approach is that in the words of Professor Lorne Sossin it acts more akin to an "on/off switch" than a "spectrum" in framing justiciability, ${ }^{125}$ thus reducing judicial discretion and setting a kind of objective yardstick. This approach, however, does not completely alienate the prudential strand, but it affords the classic strand more importance. Judge Dennis in Comer v Murphy at the Fifth Circuit outlines this approach to justiciability which centralises the classic strand. According to Judge Dennis justiciability is a function of whether a question is "constitutionally capable of being judicially decided". ${ }^{126}$ Judge Dennis's formulation incorporates the doctrine of separation of powers, American constitutional doctrine, relevant legislative frameworks and constitutional conventions relating to Congress and the United States President. ${ }^{127}$ Judge Dennis also clarifies what the question of constitutional capability excludes, namely, "federal judges' capability, intellect, knowledge, expertise or training, ... the inherent difficulty, complexity, novelty or esotery of the matter to be resolved". ${ }^{128}$ The shift from the focus on the complexity of the matter is a significant change.

It is argued that Judge Dennis's framing of justiciability demonstrates a clear emphasis on constitutional interpretation that is consistent with the classic strand and, unlike the Canadian approach, broader prudential concerns are not centralised. Even if later Judge Dennis goes on to consider prudential concerns vis-à-vis the latter parts of the Baker test, in this early framing of justiciability, Judge Dennis explicitly rejects certain concerns that could be broadly lumped into prudential concern in a broad calculus such as "federal judges' capability, intellect, knowledge, expertise or training, nor upon the inherent difficulty, complexity, novelty or esotery of the matter to be resolved". ${ }^{129}$ In Comer v Murphy, this focus on constitutional interpretation meant that there was in effect a different starting point to the justiciability analysis. There was a presumption-like effect in favour of justiciability where there were no other countervailing constitutional imperatives. Justice

$123 A E P$, above n 14 , at 324

124 At 324 citing Lamont $v$ Woods 948 F 2d 825 (2d Cir 1991) at 831.

125 Sossin, above n 15, at 666.

126 Comer, above n 14, at 869 per Dennis J (emphasis added).

127 At 869.

128 At 869

129 At 869 
Dennis's justiciability analysis was not clouded by a generalised approach to what is deemed to be political. This is seen when Judge Dennis states that: ${ }^{130}$

... in this context, "political" does not broadly relate to government, government policy, partisan or party

politics, or the political system. A case or question that is "political" only in the broad sense, ie, that it has

political implications or ramifications, is capable of being decided constitutionally by a federal court, so

long as the question has not been committed by constitutional means exclusively to the elected or political

branches.

The nuance that a case can only be political in the "broad sense" is a significant one. ${ }^{131}$ The practical effect of this approach was that the Court held that the plaintiffs' tortious claims under nuisance, trespass and negligence were justiciable. ${ }^{132}$

The focus of the classic strand is tied to the constitution and therefore it has recourse to constitutional case law as markers of reasoned judicial approach. ${ }^{133}$ Whereas the prudential inquiry is a broader one, related to a broader conception of judicial restraint. ${ }^{134}$ It is unlikely that a prudentially focused, broadly framed inquiry could lead to principled distinctions, in the same way that an approach based on constitutional interpretation could.

\section{Remedies focus}

It is argued that the United States judicial approach to the justiciability of climate change is more principled due to its focus on remedies. This is because it allows for cases to be distinguished on the facts in terms of the remedies sought. This is seen in cases such as AEP and Comer v Murphy. This approach is more discerning and less broad-brushed than the Canadian approach, which does not make distinctions in terms of remedies. In AEP the Second Circuit emphasised that the claimants were not seeking to "ask the courts to fashion a comprehensive and far-reaching solution to global climate change". ${ }^{135}$ This was a task noted to fall outside the role of the courts and is one shared by the legislature and the executive. ${ }^{136}$ The claimants in $A E P$ are seeking a more nuanced remedy, namely to: ${ }^{137}$

130 At 870

131 At 870

132 At 870

133 Jaffe, above n 66, at 1037.

134 At 1037.

135 AEP, above n 14, at 325 .

136 At 325 .

137 At 325 . 
... limit emissions from six domestic coal-fired electricity plants on the ground that such emissions constitute a public nuisance that they alleged caused, is causing, and will continue to cause them injury.

The strengths of the approach in $A E P$ is that it does not get lost in the complexity but faces the issues and its nuances head on. The Court in effect heads to Blackmun J's verbatim in Sierra Club v Morton that: 138

Must our law be so rigid and our procedural concepts so inflexible that we render ourselves helpless when the existing methods and the traditional concepts do not quite fit and do not prove to be entirely adequate for new issues?

Such an approach does not render the court helpless and it keeps room for the court to not act. Equally, in Comer v Murphy the Court noted: "Claims for damages are also considerably less likely to present nonjusticiable political questions compared with injunctive relief." ${ }^{139}$ Also, Fifth Circuit precedent in cases such as Gordon v Texas emphasises that claims for damages are not considered "a form of relief that is not judicially manageable". ${ }^{140}$ Consequently, there is symmetry between the earlier arguments about the principled approach that flows from the Baker test and the principled distinctions that can be made via a remedies focus. Some argue whether the remedy sought matters in terms of the wider discussions of justiciability and whether it is an arbitrary distinction. It is argued that it does matter because the remedies sought impact on the policy implications of a judicial decision. There is a level of pragmatism and balance involved in the remedies focus which lends itself to be more principled in the wider contest rights among competing groups.

The remedies focus encompasses evaluating the full impact of the relief sought by climate change plaintiffs. It strikes the optimum balance in the contest of rights inherent in climate change litigation. This approach builds on the principled nature of the Baker test and adds an important gloss to it.

\section{B How do Judges Determine the Justiciability of Climate Change in Canada?}

\section{Broadly framed approach and the flow-on effects of how justiciability is defined}

It is argued that the broadly framed approach to justiciability in Canada has negative consequences. It has a flow on effect in terms of the judicial determination of the justiciability of climate change. This flow-on effect is seen in Friends of the Earth where the Court affirmed the importance of an open-ended approach. ${ }^{141}$ This broadly framed approach, despite being perceived as

138 Sierra Club v Morton 405 US 727 (1972) at 755-756 per Blackmun J dissenting.

139 Comer, above n 14, at 874.

140 Gordon v Texas 153 F 3d 190 (5th Cir 1998) at 195.

141 Friends of the Earth, above n 16, at [25]. 
flexible by some, can become a guise for courts that want to avoid politically sensitive cases. It skews judicial reasoning. This is particularly in terms of the strict strand of Canadian justiciability and the associated fragmentation discussed earlier. Cases such as Re Canada Assistance Plan set up a legal test that is broadly framed. ${ }^{142}$ This is utilised by seminal Canadian cases on justiciability, such as Reference Re Succession of Quebec, to fashion a legal test for justiciability that is centred on the "courts own assessment of its proper role". ${ }^{143}$ This test is very broad compared to the six different components of the Baker test, which can also be divided into classic and prudential strands. The Canadian test, on the other hand, does not have different discrete components to it; instead the different components are subsumed together. Also there is a clear impact of the Baker test on the prevailing American case law on the justiciability of climate change, whereas Canadian case law has a fragmented effect. In Friends of the Earth the Court very much revelled in its own broadly framed approach. ${ }^{144}$ On the one hand, the Court acknowledges the usefulness of creating "criteria for a determination of justiciability, including factors such as institutional capacity and institutional legitimacy". ${ }^{145}$ It also found that determination of justiciability will involve a "diverse and shifting set of issues". ${ }^{146}$ Nonetheless, the Court reasoned that "it is necessary to leave the content of justiciability open-ended"147 and that "[w]e cannot state all the reasons why a matter may be nonjusticiable." 148 There is an inconsistency in the reasoning. The Court contends that "there will always be, and always should be, a boundary between what courts should and should not decide". ${ }^{149}$ Yet, the Court is resolute that "this boundary should correspond to predictable and coherent principles". ${ }^{150}$ It is argued that the judges in Friends of the Earth were not able to fully reconcile the contradictions in the reasoning.

The "open-textured"151 approach in Comer v Murphy is not the same as the "open-ended"152 approach in Friends of the Earth. In referencing secondary sources to support its argument about justiciability, the Court went on to centralise broad notions of institutional legitimacy without

142 Re Canada Assistance Plan, above n 52.

143 Reference Re Succession of Quebec [1998] 2 SCR 217 at [26].

144 Friends of the Earth, above n 16, at [25] (emphasis added).

145 At [25].

146 At [25].

147 At [25].

148 At [25].

149 At [25].

150 At [25].

151 Comer, above n 14, at 872 .

152 Friends of the Earth, above n 16, at [25]. 
reference to any other counterbalancing factors. ${ }^{153}$ It is argued that the Court in Auditor General foreshadowed this broadly framed approach when it stated: "An inquiry into justiciability is, first and foremost, a normative inquiry". ${ }^{154}$ This is in contrast to a constitutional interpretation approach as in the classic strand in the United States. Also these normative inquiries by their very nature are subjective and "broad brushed".

The approach in Friends of the Earth has negative consequences. The lack of clear theorisation on justiciability and an instead broadly framed approach means that there is greater chance of errors in judicial reasoning. In Friends of the Earth what the broad test effectively meant was that "Justice Barnes conflated the distinct concepts of enforceability and justiciability". ${ }^{155}$ This is with regard to Barnes J's discussion of provisions of KPIA that require an "equitable distribution" of greenhouse gas emissions across the different sectors of the economy, which were held to be "policy-laden considerations which are not the proper subject matter for judicial review". ${ }^{156}$ Therefore there were "no objective legal criteria which can be applied and no facts to be determined which could allow a court to decide whether compliance had been achieved". ${ }^{157}$ However, the glaring error in judicial reasoning is that the claimants in the case are not seeking an "equitable distribution of GHG reductions". ${ }^{158}$ Therefore it would be redundant to analyse "a possible future federal regulation to determine whether such an 'equitable distribution' has been achieved". ${ }^{159}$ The claimants are not seeking to "tell Canada how to comply with the KPIA". ${ }^{160}$ The claimants are seeking "a remedy well within the legitimate competence" of the Federal Court. ${ }^{161}$ In particular to issue a declaration that ss 5 and 7-8 have not been implemented. ${ }^{162}$

It is asserted that a remedies focus would not lead to such glaring errors in judicial reasoning. This is because the Baker test provides a framework. Despite its capacity to be interpreted broadly, it has certain key strands that cannot be avoided. These act as a check against the judiciary merely using justiciability as a pretence to avoid awkward cases. Whereas a broad test may embolden judges to

153 At [25]. See also Sossin, above n 15, at 4-5.

154 Auditor General, above n 52, at 90-91.

155 Dianne Saxe "Friends of the Earth - Les Ami(e)s de la Terre v Canada (Governor in Council) as Adjudicated by Federal Court of Appeal" (2011) J Parliamentary \& Pol L 237 at 241.

156 Friends of the Earth, above n 16, at [33].

157 At [33].

158 Saxe, above n 155 , at 241 .

159 At 241 .

160 At 241 .

161 At 241 .

162 At 241 . 
miss what is actually before the court and pontificate in the ether. This is not to say that judicial restraint is not needed, merely that there needs to be a principled approach to judicial restraint that can be tracked. Although a more tightly framed approach to justiciability can reduce flexibility, it is a trade-off that should be taken to ward off both undue judicial reticence and undue judicial activism. No matter where a person sits on the political divide, both judicial activism and judicial reticence are problematic. However, a less theorised approach as seen in Canada encourages both judicial activism and judicial reticence. Yet, what is needed in facing the complexities of climate change is a middle path that is based on the pillars of a robust framework.

\section{Mirroring the prudential strand of the United States political questions doctrine}

The current prevailing Canadian judicial approach on the justiciability of climate change mirrors the prudential strand of the political questions doctrine of the United States. This is seen in how issues are framed in cases such as Friends of the Earth and Turp. Consequently, even though Canada is often lauded for not having a United States style political questions doctrine, which some view as an intellectual straight jacket, ${ }^{163}$ the practical effect is the same. The difference is that the Canadian equivalent of the political questions doctrine does not have the order in terms of its legal reasoning that the United States has and by default it mirrors the prudential strand.

In Friends of the Earth, the Court in affirming the approaches in Doucet-Boudreau v Nova Scotia (Minister of Education) and Canadian Union Public Employees v Canada (Minister of Health) found that: ${ }^{164}$

Generally a court will not involve itself in the review of the actions or decisions of the executive or legislative branches where the subject matter of the dispute is either inappropriate for judicial involvement or where the court lacks the capacity to properly resolved it ...

The problem with this approach is that in focusing on prudential concerns, the Court is merely outlining the prudential concern in the justiciability test without actually creating a framework through which the prudential concern can be navigated. The Court states that the test for justiciability involves notions of inappropriateness for judicial involvement or notions of lack of "institutional capacity". ${ }^{165}$ Yet, the test does not create a framework to determine this like the Baker test. This means judges have more discretion and fewer checks and balances than is present with a Baker-like test. A broad notion of institutional capacity could encompass many value-laden factors, which is unlikely to lead to a

163 Henkin, above $\mathrm{n} 8$, at 622 .

164 Friends of the Earth, above n 16, at [25] (emphasis added). See Doucet-Boudreau v Nova Scotia (Minister of Education) [2003] 3 SCR 3 at [33]-[36]; and Canadian Union Public Employees $v$ Canada (Minister of Health) (2004) 244 DLR (4th) 175 (FC) at [39].

165 Friends of the Earth, above n 16, at [25]. 
principled, reasoned approach. The Court in Friends of the Earth goes on to cite Lorne Sossin's book, Boundaries of Judicial Review: The Law of Justiciability in Canada, to support their reasoning. ${ }^{166}$ Lorne Sossin argues: "Appropriateness not only includes both normative and positive elements, but also reflects an appreciation for both the capacities and legitimacy of judicial decision-making". ${ }^{167}$ Although this kind of approach gives a general idea of what might be in the legal approach, it nevertheless creates uncertainty. Prudential concerns are better characterised as a normative inquiry, involving greater subjectivity and imprecise legal markers than a constitutionally interpretative approach. This is not to say that subjectivity is inherently bad, but subjectivity needs to be balanced with some degree of objectivity to achieve a principled approach.

In Turp the Court affirmed the approach in Friends of the Earth and noted that the Federal Court of Appeal had upheld this decision. ${ }^{168}$ The application for leave to appeal to the Supreme Court was dismissed. ${ }^{169}$ The Court in Turp did not fashion its own approach to justiciability, but merely affirmed the Friends of the Earth approach to supplement its conclusion that "[i]n the absence of a Charter challenge, it appears that a decision made in the exercise of prerogative powers would not be justiciable." 170

\section{Focus on statutory interpretation}

One of the pillars of the broadly framed Canadian approach to justiciability is the emphasis on statutory interpretation, with particular recourse to United Kingdom case law. This is particularly seen in cases such as Friends of the Earth and Turp v Canada. This is unlike American cases such as Comer $v$ Murphy and AEP, which focus on constitutional interpretation in terms of the ratio. This approach is tied to the broader notion of parliamentary sovereignty. It is distinct from the doctrinaire American constitutional interpretation focus. It involves consideration of broad issues of parliamentary intent and legislative framework, which often gives mixed signals about the legislative intent. The Court in Friends of the Earth exemplifies this approach when it outlines that: ${ }^{171}$

The justiciability of all of these issues is a matter of statutory interpretation directed at identifying

Parliamentary intent: in particular, whether Parliament intended that the statutory duties imposed upon the

Minister and upon the GIC by the KPIA be subjected to judicial scrutiny and remediation.

166 At [25].

167 Sossin, above n 15 , at $4-5$.

168 Turp, above n 16, at [22] and [26]. See generally Friends of the Earth v Canada (Governor in Council) [2009] FCJ 1307.

169 See generally Friends of the Earth $v$ Canada (Minister of the Environment) [2009] SCCA 497.

170 Turp, above n 16, at [18]. See also Operation Dismantle, above n 15.

171 Friends of the Earth, above n 16, at [31]. 
The Court in Friends of the Earth puts this impetus on statutory interpretation into practice in terms of its focus on language. The Court asserts that the language of the relevant provisions of the KPIA is "clearly not mandatory". ${ }^{172}$ The Court supports this assertion based on the so-called inconsistency between the obligation created by s 7(1) (based on "an isolated and strictly literal interpretation") and the language of s 7(2) and s 6 of the KPIA. ${ }^{173}$ Section 7(1), based on a literal interpretation, is said to create a duty upon the GIC "to make all of the regulatory changes required to ensure Kyoto compliance within 180 days of the Act coming into force". ${ }^{174}$ Conversely, the wording of s 7(2) "allows the GIC at any time after the passage of the Act to make further regulatory changes to also 'ensure' that Canada meets its Kyoto obligations". ${ }^{175}$ Equally s 6 of the KPIA states that "only that the GIC 'may' make regulations". ${ }^{176}$ Overall the Court in Friends of the Earth concludes that the 180-day timeframe for Kyoto compliance is "merely directory or suggestive". ${ }^{177}$ However such a focus on statutory interpretation is a distraction from the main issues and leads to overblown conclusions. The Court is using highly academic and strained reasoning to gloss over more overtly political and ideological reasons to circumvent justiciability in this case.

Equally, the Court notes: ${ }^{178}$

This, I think, was the basis for the admonition by Lord Browne-Wilkinson in $R v$ Secretary of State for the Home Department ... to the effect that without clear statutory language the courts have no role to play to in requiring legislation to be implemented. This, he said, would tread dangerously close to the area over which Parliament enjoys exclusive jurisdiction. The language of subsections $7(1)$ and $7(2)$ is sufficiently unclear that I do not think that it was intended to override the clearly permissive meaning of the words "may make regulations" in subsection 6(1) of the Act.

This verbatim from the Court illustrates how the focus on a statutory interpretation-based approach to justiciability means that it is a broadly framed approach with associated risks in terms of consistency of legal reasoning. In particular, the Federal Court here is likely to incorrectly interpret Parliament's intent when it looks at the language of this statute. There are both literal and purposive approaches to statutory interpretation. Given that the Court acknowledges that literal interpretation is not preferable, then presumably the Court is taking a purposive approach. If so, the Court is tasked with ascertaining the legislative intent from the purpose and text of the statute. If the purpose of the

172 At [38] (emphasis added)

173 At [38].

174 At [38].

175 At [38].

176 At [38].

177 At [38].

178 At [38] citing $R v$ Secretary of State for the Home Department [1995] 2 All ER 244 (HL) (emphasis added). 
KPIA was to reduce greenhouse gas emissions, it would follow that this will have an impact on the analysis. Though the wording may in some cases indicate legislative intent, it could be equally likely that the legislature did not pay a great deal of attention to the wording or assumed that its broad legislative intent would be presumed by the courts. This focus on language, along with a broadly framed conception of justiciability, creates an environment in which judges can simply seek to avoid politically awkward cases relating to climate change, while still appearing principled to some extent by purporting to be doing statutory interpretation. The practical effect is a strained interpretation of the statute. Even if the court points to notions of parliamentary sovereignty to justify its approach, one should ask why the courts are reading down provisions of the KPIA if Parliament is sovereign. The mixing of justiciability and parliamentary sovereignty makes for an incoherence of legal principle and creates conflict between the different trajectories of equally important constitutional concepts. Admittedly the Court goes on to acknowledge that: ${ }^{179}$

While the courts fulfil an obvious role in the interpretation and enforcement of statutory obligations,

Parliament can, within the limits of the constitution, reserve to itself the sole enforcement role.

If the legislature did intend a binding obligation under s 5 of the KPIA then "a simple and unequivocal statement of such an intent would not have been difficult to draft". ${ }^{180}$ Some would argue that this kind of approach to statutory interpretation is necessary. This article asserts that it is not necessarily so. Justiciability by its nature in Canada and other jurisdictions is a concept developed vis-à-vis the common law. Although it does interact with statutory law, it can operate independently. Therefore, the focus on statutory interpretation is not sincere and that it is likely to encompass fears about the political consequences. Some scholars have argued that the reticence of this Court in applying the KPIA is tied to the fact that the KPIA was passed via a private member's Bill. ${ }^{181}$ This article asserts that even if a statute comes about through a private member's Bill, it still represents the will of Parliament and therefore courts should not be reading down provisions. It is important to acknowledge, though, that it is difficult to be definitive about the true reasons behind the judicial reasoning. It is noteworthy to mention that the Court in Turp was influenced by this kind of focus on statutory interpretation in Friends of the Earth. ${ }^{182}$ The Court in Turp held that: ${ }^{183}$

As for determining whether this decision complies with the KPIA, to reiterate the words of Justice Barnes

in Friends of the Earth ... at para 42, if Parliament had intended to impose a justiciable duty upon the

179 At [26].

180 At [33].

181 Steven Chaplin "Friends of the Earth - Les Ami(e)s De La Terre v Canada (Governor in Council and Minister of the Environment) 2008 FC 1183" (2009) 2 J Parliamentary \& Pol L 343 at 346.

182 Turp, above n 16, at [22].

183 At [26]. 
government to comply with Canada's Kyoto commitments, it could easily have said so in clear and simple language. It did not do so.

The Court in Turp found that not only did the Parliament not heed this salutation, nor did any of the provisions of the KPIA expressly or impliedly change the royal prerogative. ${ }^{184}$ This meant that the claimant's challenge could not succeed as Canada's "decision to withdraw from the Kyoto Protocol did not violate the KPIA nor the principle of the rule of law". ${ }^{185}$

In sum, the Canadian focus on statutory interpretation in framing a position on the justiciability of climate change leads to legal reasoning that is not consistent with a principled approach. This is because of the inbuilt broadly framed approach to justiciability in Canada being mixed with notions of parliamentary sovereignty. The errors in the reasoning are based on what the court is purporting to be doing, namely a purposive as opposed to a literal approach to statutory interpretation. The corollary of this is that if the Canadian courts are actually undertaking a bona fide purposive approach, then they should consider the purpose of the KPIA in its assessment of justiciability.

\section{CONCLUSION}

This article has canvassed some key arguments about the differences between Canadian and American courts in terms of their approaches to the justiciability of climate change. A common theme between the jurisdictions has been the flow-on effect of how justiciability is initially framed. It impacts how courts approach the justiciability of climate change. This is not surprising given that climate change law is still at its inception and there is much more development of the law to follow.

The juxtaposition of the prevailing approaches of the two nations provides a salient study in judicial responses to the complexities of climate change and the intermingling with existing concepts of tort, public and environmental law. Fragmentation and coherence at the initial stage have important impacts down the feedback loop of law. In regards to the United States, a clear framework in Baker, coupled with a focus on constitutional interpretation and remedies, provides a path for principled distinctions to be made. Conversely, the Canadian approach, lacking a clear structure initially, and subsequently mirroring a broad focus on prudential concerns and statutory interpretation, results in incoherence and flaws in legal reasoning. Although courts are not completely out of touch with environmental concerns, the justiciability doctrine has been fashioned to create an important constitutional balance. Nevertheless, it is important to enquire whether the legal reasoning is being used to avoid important issues. There is also an important nuance to be taken from this article, which is that flexibility within a framework is not the same as flexibility outside a clear framework. In the United States, the courts have built on the Baker test to fashion a position on the justiciability of

184 At [26].

185 At [26]. 
climate change that is both flexible and also congruent with certain parameters. Whereas the courts in Canada have been flexible without such congruence.

The genius of the Baker test is that it is premised on the nuance that a case with some political aspects does not necessarily mean that the case will involve non-justiciable political questions. This impact of Baker is seen in cases such as Comer v Murphy and AEP, which carried through this nuance to its reasoning about climate change. The Baker test provides the framework to separate truly political questions from mere political cases; it shows the very close intersection between the general justiciability doctrine and the jurisprudence of the justiciability of climate change in the United States.

The use of the classic strand of the political questions doctrine in climate change cases such as Comer v Murphy and AEP gives the American justiciability of climate change jurisprudence greater legal certainty and predictability. It also reduces arbitrariness by not allowing the so-called difficulty or novelty of an issue to become a barrier to its full adjudication. The remedies focus is another pillar of the effectiveness of the justiciability of climate change jurisprudence in America. The remedies focus allows courts a fair way of distinguishing between cases that impinge on the separation of powers and ones that do not. It also accords with notions of judicial manageability of matters as some matters involve standards that have been identified in previous case law.

Equally, in Canada, when general justiciability doctrine is broadly framed, as in key cases such as Reference Re Canada Assistance Plan (BC) and Reference Re Succession of Quebec, this allows the courts to create a very broadly framed approach to the justiciability of climate change as seen in the open-ended approach of the Canadian Supreme Court in Friends of the Earth. This open-ended approach allows judges to make arbitrary decisions on climate change matters that forgoes the need to give principled reasons. Yet, strong reasoning is the bedrock of a strong jurisprudence.

The Canadian climate change jurisprudence on the justiciability of climate change as exemplified by Friends of the Earth in effect mirrors the prudential strand of the United States political questions doctrine. However, unlike the United States, which incorporates both the prudential and classic strands, the Canadian equivalent is both incomplete and unbalanced. This lack of balance is not without consequence. It accords greater power to judges which goes against the fairmindedness envisaged by constitutional principles such as the separation of powers. It is argued that justiciability doctrine should exist in its own right and not be governed by the parameters of the doctrine of parliamentary sovereignty. In Canadian cases such as Friends of the Earth and Turp, the courts effectively put the onus on Parliament to determine justiciability. However, this is an odd approach. The KPIA has been passed by the Canadian Parliament. It had set some duties and deadlines with respect to climate change. Once these duties are not met, there should be a prima facie case for justiciability. Otherwise the Canadian courts could be perceived as using very strained legal reasoning to defend a hidden ideological position. 
In effect, the open-ended approach of the Canadian justiciability of climate change will have negative consequences for addressing the collective problem of climate change as opposed to the open-textured approach in the United States. 